\title{
Del algodón al desempleo: la "población indígena" en Misión Nueva Pompeya, Chaco: 1970-2016
}

\author{
From cotton to unemployment: The "indigenous population" \\ in Nueva Pompeya, Chaco $1970-2016$ \\ Roberto Muñoz \\ Instituto de Investigación en Humanidades y Ciencias Sociales \\ (IdihCs-unlp-Conicet). La Plata, Argentina \\ munozroberto8288@yahoo.com \\ ORCID: https://orcid.org/oooo-0002-I232-9853 \\ ISSN-OI85-4259; e-ISSN: 2007-9I76 \\ DoI: http://dx.doi.org/Io.28928/ri/882020/aot3/munozr
}

\begin{abstract}
Resumen
Misión Nueva Pompeya, ubicada en el departamento General Güemes, en la provincia de Chaco, Argentina, es uno de los asentamientos más antiguos de la región (primeros años del siglo xx). Actualmente se asienta sobre 20 ooo hectáreas de propiedad comunitaria a nombre de una asociación indígena en donde alrededor de $60 \%$ de su población se clasifica como perteneciente a la etnia wichí. Se analizan las transformaciones ocurridas durante las últimas décadas, en términos de la reproducción social de los habitantes identificados como indígenas, en dos momentos históricos: sus condiciones en la década de 1970-para lo cual contamos como fundamento el exhaustivo trabajo de campo realizado, a pedido del gobierno provincial, por un grupo interdisciplinario de científicos sociales-, y la situación en los últimos decenios, para lo cual utilizaremos observaciones realizadas en nuestro trabajo de campo durante2016, entrevistas a informantes claves y fuentes secundarias.

Palabras claves: Argentina, Provincia de Chaco, comunidades indígenas, reproducción social, propiedad comunitaria.
\end{abstract}

\begin{abstract}
Misión Nueva Pompeya, located in the General Güemes department, in the province of Chaco, Argentina, is one of the oldest settlements in the region (early years of the 20th century). Currently, it is based on 20,000 hectares of community property in the name of an indigenous association and about $60 \%$ of its population is classified as belonging to the Wichí ethnic group. Are analyzed the transformations that have occurred during the last decades, in terms of the social reproduction of the inhabitants identified as indigenous in two historical moments: their situation in the I970s-for which we count as an input the extensive field work conducted, at the request of the provincial government, by an interdisciplinary group of social scientists-, and the situation in recent decades, for which we will use our observations made in our fieldwork, interviews with key informants and secondary sources.
\end{abstract}

Key words: Argentina, Chaco province, indigenous communities, social reproduction, community property

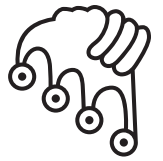

IZTAPALAPA

Agua sobre lajas 


\section{Introducción}

La región del Chaco argentino se ha caracterizado históricamente por su incorporación relativamente tardía al proceso de producción capitalista, lo que la constituyó en el último refugio de las comunidades aborígenes ante el avance del capital. A finales del siglo XIX y principios del xx las incursiones militares permitieron la ocupación definitiva del territorio controlado por los indígenas, la destrucción de su economía basada en la caza, la pesca y la recolección y, como resultado de ello, la creación de una masa de población disponible para el trabajo asalariado (Iñigo, 1984). De ese modo, a partir de la década de 1920 el espacio agrario chaqueño se incorporó como principal productor de algodón de la Argentina impulsado por el programa estatal de colonización agrícola, que se basó en la radicación de pequeñas y medianas unidades de producción (Roze, 2004). Estas características, por un lado, habilitaron el desarrollo de diversos estudios sobre la evolución del algodón y sus sucesivas crisis, con un sesgo hacia estos sujetos (Miranda, 1955; Besil, 1970; Schaller, 1999; Manoiloff, 200I; Moglia 2007; 2008; 20II). Por otro, como señala Gordillo (2006), la antropología argentina va a definir el Gran Chaco como su espacio etnográfico más importante, el territorio "donde la antropología buscaría materializar (...) el 'casillero salvaje' asignado a la disciplina" (Gordillo: 2006; 229).

En la década de 1970, los trabajos antropológicos, dominados por la corriente que se dio en llamar etnología fenomenológica, postulaban la inmutabilidad de las comunidades indígenas. Se proponían comprender su cultura desde la perspectiva de sus miembros, haciendo abstracción de las condiciones sociales e históricas (Bórmida, 1969; 1976). Más recientemente, Trinchero (1995; 1998) considera que el concepto marxista de subsunción formal y real del trabajo al capital no sirve para explicar la realidad chaqueña. En cambio, introduce el concepto de "subsunción indirecta", que reflejaría mejor la supuesta persistencia de modos de producción doméstica. Es decir, según este autor, en el Chaco no se presenta un proceso de proletarización, sino que se desarrollan otros sujetos (campesinos y comunidades étnicas), a través de los mecanismos particulares de la subsunción indirecta. De 
manera similar, Gordillo (2006) analiza las formas de inserción de estas comunidades en el Estado argentino, intentando rescatar prácticas contrahegemónicas que les permitirían una independencia relativa respecto de la explotación capitalista y las relaciones asalariadas.

Desde una perspectiva contraria a estas interpretaciones dominantes dentro de las ciencias sociales, en este artículo nos interesa retomar como punto de partida el trabajo realizado por un grupo interdisciplinario de investigadores entre 1969 y I970 en la provincia de Chaco, pero que no se editó hasta 1995. Nos referimos al minucioso informe dirigido por Esther Hermitte y publicado como Estudios sobre la situación de los aborígenes de la provincia del Chaco y políticas para su integración a la sociedad nacional. A pesar de lo que el título hace suponer a primera vista, en relación con los requerimientos del gobierno provincial del momento, que había solicitado este trabajo, los autores muestran que:

las comunidades aborígenes del Chaco y la estructura social de la provincia no aceptan una descripción de sus características acorde con el tipo ideal de "sociedad dual". El modelo que puede dar cuenta de la configuración social chaqueña debe tomar como dato originario del sistema que la integración de los sectores aborígenes es un fenómeno temprano dentro del proceso de estructuración de la sociedad chaqueña y que su situación actual, primero, no es exclusiva del grupo aborigen, y segundo, que encuentra su explicación en el proceso de desarrollo de las fuerzas productivas de la provincia, en la estructura ocupacional resultante y en el sistema de clases que le corresponde. (Hermitte et al., tomo I* 1995: 36)

De esta manera, el análisis de los diferentes casos que abordaron - tres asentamientos rurales (Misión Nueva Pompeya, Colonia Aborigen Chaco y Cabá Nará) ubicados en distintos puntos del interior provincial y el barrio Toba de Resistencia- puso el eje en las relaciones concretas de producción de las que participaban los llamados indígenas. Es decir, a diferencia de los autores reseñados más arriba, centrados generalmente en la reconstrucción de experiencias a partir de la memoria de los propios sujetos bajo estudio, aquí se vuelve determinante no pasar por alto o dar un lugar secundario al proceso histórico de proletarización de la población indígena.

Compartiendo estas premisas, nos proponemos describir las transformaciones ocurridas desde entonces en Misión Nueva Pompeya, en términos de la reproducción social de los habitantes identificados como indígenas y abonar al conocimiento acerca de las formas de inserción social, en términos de clase, de esta población. Nuestro análisis busca resaltar el componente estructural de la determinación de 
clase de dicha población. Esto no significa negar que los sujetos sean el resultado de múltiples determinaciones, sino sostener que estas se ordenan jerárquicamente y configuran un sistema dentro del cual la relación de clase es la que organiza al resto. Las identidades étnicas son producto de esta tensión, no como meros "inventos" sino como formas transmutadas de lo real, transmutaciones que pueden conservar algunos elementos reales con exclusión de otros o incluso conservarlos todos pero alterando las relaciones que los unen. Así, clase, nación, género, etnia, ciudadanía, etc., son categorías que definen identidades de modo conflictivo y complejo, implicando subordinaciones y rebeldías. La separación analítica no debe hacernos olvidar que todas estas categorías actúan juntas en cada persona, lo que constituye la dificultad más importante (Sartelli, 1996).

Con tal fin, consideramos las transformaciones ocurridas al respecto durante las últimas décadas, a partir de la comparación de dos momentos históricos: las condiciones imperantes en la década de 1970, para lo cual contamos fundamentalmente con los datos recabados durante el trabajo de campo realizado por el grupo dirigido por Hermitte, y la situación en los últimos decenios, que abordaremos por medio de observaciones in situ, entrevistas a informantes claves (integrantes de la comunidad indígena, agentes estatales de la localidad, entre otros) y charlas informales con vecinos durante nuestra estadía, complementadas con los datos estadísticos disponibles (censos de población, agropecuarios e informes de otros organismos públicos). El análisis de la población reconocida como indígena de esta localidad en estos dos momentos históricos nos permitirá delinear las transformaciones históricas que experimentó y su dinámica.

\section{Los orígenes del asentamiento}

En 1900 se organizó en el territorio del Chaco la Misión franciscana de Nueva Pompeya, a cargo de los misioneros del Colegio de San Diego, de la provincia de Salta, con la finalidad de reducir a los grupos de procedencia wichí. ${ }^{1}$ Aunque estos

1 Se trató de los padres franciscanos pertenecientes a la Sagrada Congregación de Propaganda Fide, con una trayectoria misional en Argentina de larga data, pero que se asienta en los territorios nacionales de Chaco y Formosa a inicios del xx. Para un análisis de su intervención en diferentes momentos, en otros espacios y con otros grupos étnicos del norte argentino véanse: Ana Teruel (2005), Misiones, economía y sociedad. La frontera chaqueña del Noroeste argentino en el siglo XIX, Buenos Aires, Universidad Nacional de Quilmes y Gabriela Dalla-Corte Caballero (2014), San Francisco de Asís del Laishí. Sensibilidades to- 
grupos habitaban la zona aproximadamente desde el siglo xviI, el asentamiento tuvo su origen justamente con la fundación de la misión. ${ }^{2}$ Por decreto presidencial de Julio Argentino Roca, se autorizó su fundación en un terreno de 20000 hectáreas en pleno Impenetrable Chaqueño (mapa I). Su administración y gobierno quedaron a cargo del prefecto del Colegio de San Diego y bajo la supervisión del Ministerio del Interior. Su objetivo principal era contribuir a la nacionalización y civilización de la población indígena, en este caso de procedencia wichí, teniendo la religión católica como vehículo para lograrlo:

El objeto principal y la razón de ser de nuestras Misiones, es la catequización y evangelización del indio, y, a este fin, deben encaminarse todos los esfuerzos y trabajos de los Pp. Misioneros. (...) Es útil, y aún necesario, instruir a éstos en los diferentes trabajos agrícolas, ganaderos e industriales, que les permita adquirir medios de vida para sí y los suyos, para que, así, remedien algunas de sus necesidades materiales, se dediquen a lo más importante e indispensable; su instrucción en las verdades de la Fe y en la práctica de los deberes Cristianos (Reglamento para el régimen de las Misiones Franciscanas del Chaco Argentino, 1928).

Detrás de esa tarea se buscaba la sedentarización y el control de la población indígena para su sometimiento como fuerza de trabajo asalariada (Iñigo, 1984; Teruel, 2005; Musante, 2018). ${ }^{3}$

bas y franciscanas en una misión indígena (Formosa, 1900-1955), Prohistoria Ediciones

Hacia el siglo xvi los wichí habitaban las zonas occidentales del Chaco Central Austral, que integran la región del Gran Chaco, principalmente en la margen izquierda del río Bermejo. Tiempo después, presionados por la invasión de los ava guaraníes y su propio crecimiento demográfico, se desplazaron hacia el norte del río Bermejo y hacia el sureste de la región chaqueña, donde se ubicó la misión franciscana. Actualmente, en Argentina como en la mayoría de los países latinoamericanos, se considera constitucionalmente como criterio válido para la definición de lo indígena un concepto marcadamente subjetivista, y que se basa en la autopercepción o el autorreconocimiento de los sujetos bajo estudio. Ello fue acompañado de herramientas legales que pasaron a considerar al indígena como un ciudadano singular con derechos especiales. Bajo estos nuevos criterios, en Argentina se registran 50419 personas que se reconocen como wichí, de los cuales 4 629 se asientan en la provincia de Chaco (INDEC, 2015).

3 "El objeto principal y la razón de ser de nuestras Misiones, es la catequización y evangelización del indio, y, a este fin, deben encaminarse todos los esfuerzos y trabajos de los pp. Misioneros. (...) Es útil, y aún necesario, instruir a éstos en los diferentes trabajos agrícolas, ganaderos e industriales, que les permita adquirir medios de vida para sí y los 
Mapa I:

Ubicación de Misión Nueva Pompeya en la provincia de Chaco, Argentina.

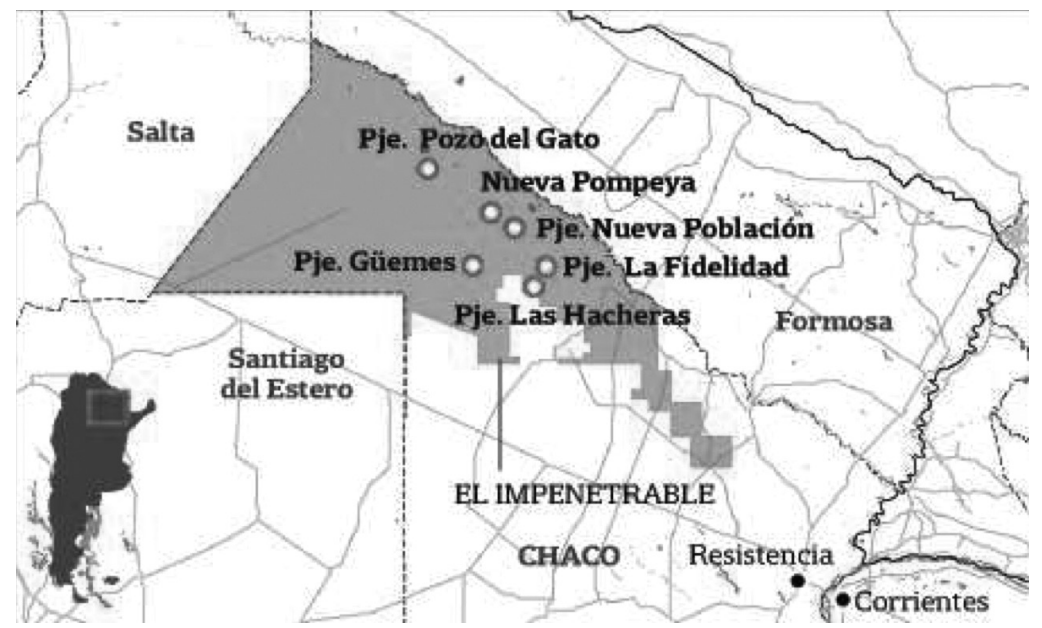

Fuente: La Nación.

En 1904, con el edificio de la misión ya terminado, los frailes lograron que algunos habitantes de la zona construyeran sus ranchos alrededor del inmueble y comenzaran a ser educados en el cultivo de la tierra. Luego de un lapso corto de aprendizaje, a estos pobladores, que ya estaban integrados al circuito estacional de la zafra de azúcar en Salta, se les entregó una parcela en la que desarrollaban cultivos para autoconsumo y el excedente lo compraba la misión (Hermitte et al., 1995). De todas formas, los avances en relación con los objetivos de la misión eran paupérrimos: un informe de 1909 indicaba que para ese año se registraban 36 hectáreas sembradas con maíz, mandioca y batata, de manera colectiva y bajo el control y la supervisión directa de los misioneros, a las que se agregaban solo io hectáreas repartidas en lotes entre la población reducida (Teruel, 2005).

Ya con la misión en funcionamiento, en I9I4 se emitió un segundo decreto presidencial, que modificaba el de 1900, debido a que "dicho acuerdo estableció ciertas condiciones que en la práctica son difíciles de realizar a causa de las modalidades

suyos, para que, así, remedien algunas de sus necesidades materiales, se dediquen a lo más importante e indispensable; su instrucción en las verdades de la Fe y en la práctica de los deberes Cristianos" (Reglamento para el régimen de las Misiones Franciscanas del Chaco Argentino, 1928). 
de los indígenas, las condiciones del terreno, las dificultades de las comunicaciones, etc." (Argentina. Poder Ejecutivo, 1914). Básicamente, la principal modificación se limitaba a bajar las pretensiones de "reducción" de indígenas. En el artículo $8^{\circ}$ se establecía que:"Cuando los Misioneros tuvieren reducidas y radicadas sesenta familias indígenas, el Poder Ejecutivo otorgará, libre de todo gravamen, al Prefecto de Misiones o al representante legal de las mismas, los títulos definitivos de propiedad de la tierra". Esto implicaba bajar cerca de 50\% la cantidad de familias asentadas que inicialmente el Estado exigía a la misión para proceder a la cesión de títulos de propiedad a los franciscanos. A su vez, también se acortaban los plazos para la entrega de títulos provisionales a los indígenas: "Dentro de los tres meses primeros desde el otorgamiento de los títulos de propiedad (...), los misioneros darán a cada familia indígena que estuviere en posesión del lote rural un título provisorio de propiedad del mismo y del solar en el pueblo, con la obligación de poblarlos por sí mismos y cultivarlos" (Argentina. Poder Ejecutivo, 1914, Art. $9^{\circ}$ ).

Esta flexibilización de los requisitos puede ser tomada como indicativa de las dificultades y el carácter más bien marginal de esta forma de radicación de la población indígena, a cargo de los franciscanos. Teniendo en cuenta que, para la época, distintas estimaciones calculaban una población indígena total de alrededor de 15 ooo personas (Secretaría de Trabajo y Previsión. Consejo Agrario Nacional, 1945: 56), el decreto exigía un piso de apenas 60 familias asentadas para hacer entrega de títulos. En términos comparativos, ya en la década de 1920, dentro del mismo territorio chaqueño, solo el ingenio Las Palmas había acogido en sus tierras, como fuerza de trabajo para la zafra azucarera, a I 200 indígenas (Iñigo, I973; García, 1977). Es decir, los mecanismos estatales tercerizados a través de una orden religiosa para la incorporación a la sociedad nacional de la población indígena tuvieron, al menos en el Territorio Nacional de Chaco, una capacidad reducida con respecto a su incorporación directa por las actividades que significó el avance del capital en la región.

En el mismo año en que se firmó el decreto de modificación también se aprobó el reglamento interno de la Misión. Se trataba de un documento compuesto por 87 artículos en el que se regulaban todos los aspectos de la vida de las familias indígenas en la Misión (Secretaría de Trabajo y Previsión. Consejo Agrario Nacional, 1945: 270-279). De su análisis se desprende, en primer lugar, el alto grado de disciplina que se pretendía imponer a los indígenas reclutados. Además, a pesar de la intensión de destinarlos a la actividad agrícola en parcelas entregadas gratuitamente, se resalta la importancia de su empleo como fuerza de trabajo en las tareas generales de la Misión. ${ }^{4}$

4 A modo de ejemplo, véase los siguientes artículos del reglamento interno: "Art. 30: Du- 
También es interesante observar que la alimentación diaria de las familias era garantizada por los propios misioneros, bajo contraprestación laboral.

Por otra parte, entre las disposiciones generales del reglamento se establecía que:

Cuando algún propietario, industrial u obrajero, quiera llevar indios de la Misión para sus trabajos, los pedirá al Superior, quien se los mandará de entre los que aún no tengan chacras en propiedad, y que voluntariamente quieran ir, conviniendo previamente el salario que les pagará, y reservándose el derecho de presenciar el pago, por sí mismo o por intermedio de otra persona de su confianza (Secretaría de Trabajo y Previsión. Consejo Agrario Nacional, 1945: 272).

De esta manera, los responsables de la Misión también fungían como una suerte de contratistas de mano de obra.

Para mediados de la década de 1930, el funcionamiento de la Misión entró en crisis, algunos frailes abandonaron el asentamiento $y$ otros fallecieron $y$ no fueron reemplazados. En 1948 murió el último de ellos y al año siguiente retiraron todas sus pertenencias para enviarlas a la Misión San Francisco de Asís del Laishí, ubicada en el vecino Territorio Nacional de Formosa. Resulta especialmente ilustrativo de la descomposición de la experiencia franciscana un informe del Comisario de las Misiones Franciscanas elaborado en 1943, en respuesta a un requerimiento de las autoridades del Consejo Agrario Nacional. Se trata de una descripción certera de la condición de reservorio de fuerza de trabajo al borde de la subsistencia que caracterizaba las misiones franciscanas en general y la de Nueva Pompeya en particular.

En Nueva Pompeya (Chaco) habitualmente castigada por la sequía, la aridez de las tierras y el avance letal de la subvegetación boscosa, el número de los indios fluctúa entre 150 y 200. No habiendo producción para la manutención ni ingresos, éstos tienen que conchabarse por los alrededores. (...) El indio no relaciona las ideas de esfuerzo y resultado en común; en la práctica, lo mismo le da. Quiere su ración diaria y su salario. Sin más aspiraciones ni teorías. (...) Las tierras adjudicadas precaria-

rante los primeros seis meses de su incorporación a la Misión, los indios se ocuparán en trabajos de beneficio y utilidad común (...) sin otra remuneración que el alimento, vestidos, medicinas y enseres domésticos. (...) Art. 38: cada mañana, al toque de la campana se presentarán todos los que no tuvieren ocupaciones propias (...) a que se les señale qué deberán ejecutar en el día; Art. 39: los que trabajen solo medio día en sus chacras, deberán trabajar el otro medio día en trabajos que se les señalaren" (Secretaría de Trabajo y Previsión. Consejo Agrario Nacional: 1945; 272-274) 
mente a las misiones son todas fiscales y todavía no hay indígenas propietarios. (...) La Misión Nueva Pompeya, por su posición tan lejana en una región tan internada del Chaco, con las características adversas y desalentadoras ya mencionadas, no tiene perspectiva de adelanto, y será necesario cambiarla o abandonarla. (Secretaría de Trabajo y Previsión. Consejo Agrario Nacional: 1945; 290)

En resumen, la misión religiosa fue parte de la política estatal para incorporar a la economía nacional a los grupos indígenas vencidos militarmente. Los propósitos declarados, tanto por los funcionarios estatales como eclesiales, de lograr la radicación del indígena en tierras aptas para la explotación agropecuaria y finalmente convertirlos en propietarios, no se verificaron en la realidad. En la práctica la misión funcionó como un reservorio de fuerza de trabajo para los ingenios, obrajes $y$, de manera predominante a partir de la década de 1920, en chacras algodoneras. Esto quedó reflejado tanto en el reglamento interno, con las disposiciones que establecía para ofrecer a terceros la fuerza de trabajo asentada en la misión, como en el balance tardío que realizaron los propios franciscanos que, como vimos más arriba, señalaban la necesidad de "conchabarse por los alrededores" que tuvieron los indígenas, ante el fracaso de los proyectos de autosubsistencia que intentaba estimular la misión.

\section{La Dirección del Aborigen: de la cosecha algodonera al coo- perativismo}

En 1970, año en que el equipo de investigadores dirigido por Hermitte realizó su trabajo de campo, en la comunidad de Nueva Pompeya operaba la Dirección Provincial del Aborigen, a través de un grupo de empleados y voluntarios (integrado, entre otros, por dos monjas, una enfermera y una maestra). A nivel provincial, la principal actividad económica de esta entidad estatal creada en 1958 bajo la órbita del Ministerio de Agricultura y Ganadería de Chaco estaba relacionada con el cultivo y la venta de algodón por parte de los indígenas. ${ }^{5} \mathrm{El}$ organismo reflejaba

5 Con la provincialización de los Territorios Nacionales, entre los que se encontraba Chaco, en la década de 1950, se avanzó en la descentralización de las instituciones abocadas a la población denominada indígena. Así, en 1956 fue disuelto el organismo nacional de aplicación de la política indigenista desde 1946, la Dirección de Protección al Aborigen. De esta manera, con la supresión del único organismo nacional especializado, se produce una dispersión de la política indigenista, siendo compelidas las provincias a crear dentro de sus jurisdicciones los organismos encargados de esta temática. Con esta 
la visión estatal de la cuestión indígena como un problema eminentemente rural con posibilidades de encararlo en términos de promover la inserción productiva de esta población como forma de lograr su integración social. Esta perspectiva queda explícitamente asentada al observar los artículos del Reglamento de funciones del Ministerio de Agricultura y Ganadería de la provincia en los que se indica la misión asignada a esta Dirección:

Art.78: La Dirección del Aborigen tendrá como misión proveer a la radicación estable de los aborígenes en explotaciones agrícolas por cuenta propia y a la creación o estímulo de todas aquellas actividades productivas de ámbito agrario o que elaboren materia prima de origen agrario y que favorezcan la elevación integral del nivel de vida de los mismos (Archivo Histórico de la Provincia del Chaco. Legajos Aborígenes s/f.).

De esta manera, los proveía de algunos insumos, tales como semillas, agroquímicos y herramientas, para llevar adelante la producción. También concedía créditos en provisiones (una lista limitada de productos: grasa, harina, yerba, azúcar y fideos) durante los meses anteriores a la cosecha. Estos mecanismos, si bien tenían alcance provincial, operaban fundamentalmente en Colonia Aborigen, ubicada hacia el centro algodonero de la provincia, donde la Dirección tenía su sede central y una parte de la población reconocida como indígena disponía de pequeñas parcelas sobre tierras fiscales cuya producción algodonera era comercializada a través de esta institución.

La situación en Misión Nueva Pompeya, por su ubicación - donde la aptitud agrícola para el desarrollo de cultivos era demasiado limitada-, era diferente. La Dirección comienza a funcionar en el asentamiento en 1969. Hasta entonces las principales actividades económicas desarrolladas en esta comunidad rural eran la ganadería de monte, la cosecha de algodón y la "marisca". Respecto a la segunda, esta producción no se realizaba en la misma zona, sino en el espacio rural de Castelli. Nueva Pompeya, junto con el resto de los parajes ubicados más al norte, proveía la fuerza de trabajo para la cosecha. Según los datos arrojados por el grupo de Hermitte, hasta 1969 prácticamente I00\% de la población "indígena” de Misión Nueva Pompeya migraba a la cosecha (Hermitte et al., tomo II, 1995). El periodo de zafra

descentralización cada provincia cobra protagonismo en el tratamiento de la cuestión indígena. En ese marco es que el estado chaqueño crea la Dirección Provincial del Aborigen. 
se extendía de enero a mayo/junio, meses durante los cuales la gran mayoría de la población de la localidad tenía un trabajo retribuido. Un número más reducido era nuevamente convocado en noviembre o diciembre para la carpida. En general, se movilizaba la familia completa a cosechar, $y$ todos desde los seis u ocho años de edad participaban en la tarea. El viaje hasta Castelli se hacía a pie y cubrir esa distancia les llevaba por lo menos dos semanas. Uno de nuestros entrevistados, Felipe, wichi de 7I años, oriundo de El Sauzal, paraje cercano de Nueva Pompeya, recordaba: "Cada uno ya tenía su patrón y se iba derecho de acá a donde estaba el patrón, iban en burrito de aquí con toda la familia. Toda la familia, tres o cuatro burros llevaban. Y se iban. A la mañana temprano se iban, viajaban y a las doce paraban y a las cuatro o cinco de la tarde ensillaban otra vez y seguían" (entrevista a Felipe, wichi de 7I años, Nueva Pompeya, 15/10/2016).

Un obrero experimentado lograba levantar alrededor de $80 \mathrm{~kg}$ de algodón por jornada. El pago era a destajo y se le descontaba la mercadería que consumiera durante su estadía en las explotaciones, vendida por el mismo dueño del establecimiento en el que trabajaban. En general, los cosecheros gastaban todo el dinero que conseguían durante su misma estancia en Castelli. El resto del año debían obtener otros medios de subsistencia.

Las otras fuentes de ocupación consistían en la caza y recolección de alimentos en el monte. Respecto a la primera, la realizaban para alimentarse y también para la venta de pieles de animales. Esta era la principal forma de subsistencia de gran parte de la población fuera de la época de cosecha, pero la venta de las pieles "apenas daba un poco de dinero que muchas veces no alcanzaba para comprar la mercadería para comer (...) Por lo tanto, esa era una época de hambre" (Hermitte et al., tomo II, I995: 65).

En el mismo sentido, uno de los entrevistados recordaba que hacia esa época: "Cada año, cuando pasaba ese trabajo [la cosecha en Castelli] después volvía acá y mariscaba: conejo, avestruz, miel, todo eso..." (entrevista a José, wichí de 65 años, Nueva Pompeya, 06/10/2006).

También, aunque en menor medida, encontraban ocupación en algunas actividades ocasionales. Se señala que durante algunos años de la década de 1950, habitantes de Nueva Pompeya lograron emplearse en un paraje cercano, El Pintado, como obreros temporales en la construcción de los edificios públicos que se estaba realizando allí. Al respecto, el ya citado informante wichí recordaba que:

El Pintado era el pueblo más famoso, en esa época había administración pública. Toda la gente de acá iba allá para poder vender animales. Pero ahora creció más Sauzalito. No quedó nada, quedan los edificios, así parece que se derrumbó. Y en 
esa época toda la zona esta se iba al Pintado a buscar guías para animales. Correo, comisaría, juzgado de paz, negocios, todo estaba en el Pintado (entrevista a Felipe, wichi de 7I años, Nueva Pompeya, 15/10/2016).

Otras ocupaciones, también escasas, eran los trabajos de desmonte, corte de leña para el almacén o limpieza de la escuela.

Con la entrada en funciones de la Dirección Provincial del Aborigen en 1969, el esquema ocupacional que describimos más arriba se modifica parcialmente. A partir de su accionar se desarrollan nuevas fuentes de trabajo. Si hasta entonces migraba casi I00\% de la población denominada indígena, en 1970 esa proporción se había reducido considerablemente: la migración temporaria para la cosecha algodonera de ese año había involucrado solo a 50\% de la fuerza de trabajo masculina indígena ocupada y a $38 \%$ de la mano de obra femenina ocupada. A su llegada, la Dirección - con el apoyo del Obispado de San Roque en Sáenz Peña- impulsó el armado de una cooperativa de trabajo, que va a quedar inscrita como tal a finales de i97i bajo el nombre de Cooperativa de Trabajo Agrícola de Producción e Industrialización Nueva Pompeya Limitada. ${ }^{6}$ Inicialmente, su actividad estuvo centrada en el desmonte para hacer agricultura de autoconsumo y en la comercialización de artesanías confeccionadas por la población aborigen. Estos trabajadores percibían su pago en especie: $2 \mathrm{~kg}$ de harina, fideos, yerba y azúcar cada dos días y a su vez recibían el almuerzo en el lugar de trabajo. Luego de esta primera etapa, rápidamente el obraje se convirtió en la principal actividad, con la producción de postes y durmientes de quebracho. Pronto la cooperativa llegó a contar con un aserradero propio, un grupo electrógeno y tres tractores. Según señala Iñigo (200I),

6 A lo largo de gran parte del siglo xx, cuando la economía chaqueña giró alrededor del sistema productivo algodonero, las cooperativas agrícolas tuvieron un lugar preeminente (Miranda, I955; Besil, 1970; Schaller, 1999; Manoiloff, 200I; Moglia 2007; 2008; 201I) Como señala Roze (2006), este instrumento organizativo fue de vital importancia para la constitución de una burguesía agraria en la provincia y para transformar al productor mercantil en productor capitalista con posibilidades de disputar una porción del mercado con otros competidores de la rama. Este sistema, que dinamizaba al conjunto de la economía provincial, entra en crisis en la década de 1960 y con él las históricas cooperativas algodoneras. Más recientemente surgen otras múltiples y nuevas experiencias cooperativas. Es nuestra hipótesis que a diferencia de las primeras, estas últimas ya no tienen como propósito central insertarse competitivamente en el mercado, sino lograr desarrollar emprendimientos productivos sustentables a partir de su inserción en redes alternativas de producción y comercialización junto a otras entidades del sector, organismos estatales y ONG nacionales e internacionales, con la finalidad de dar ocupación a parte de la población expulsada del sistema algodonero. 
en el período de auge de la cooperativa desapareció la emigración estacional para trabajar en la cosecha algodonera. Más aún, indígenas de otros parajes del norte chaqueño migraron hacia Misión Nueva Pompeya. Este hecho llegó a motivar que un vocero de la Federación Agraria pidiera la intervención del gobierno nacional y provincial porque, dijo, la cooperativa no permitía salir a los indios para la cosecha (Iñigo, 200I* 298).

De ese modo, el funcionamiento de la cooperativa entraba en contradicción con los intereses de la burguesía algodonera. Al garantizarle ciertos medios de vida en su lugar de residencia, una parte importante de la fuerza de trabajo necesaria para la cosecha dejaba de migrar a Castelli. En otro trabajo hemos descrito la crisis del algodón que estalla en la segunda mitad de la década de 1960 en Argentina, y en particular en Chaco, espacio donde se concentraba el grueso de la producción (Muñoz, 2016; 2018). De todas formas, más allá de la caída de la superficie cultivada que se registra en esos años, la cosecha algodonera seguía requiriendo una relativamente elevada cantidad de fuerza de trabajo. De hecho, su mecanización no se generalizaría hasta la década de 1990. Ante esta situación, las quejas de la Federación Agraria Argentina surtieron efectos. El titular de la Dirección del Aborigen, René Sotelo, comenzó a poner trabas a la cooperativa y una de las medidas de mayor peso fue la de restringir hasta el mínimo los permisos de tala y comercialización de postes, lo cual impedía el progreso de la empresa. Así, para mediados de 1972 la venta de la producción de la cooperativa se reducía a un tercio (Colombres, 2004).

En este punto es importante no pasar por alto el contexto político que atravesaba la provincia en estos primeros años de la década de i970 y la inserción política del grupo de voluntarios religiosos que dirigían la cooperativa. Estos formaban parte de la corriente Sarcedotes por el Tercer Mundo. A su vez, la principal referente, la monja Guillerma Hagen, tenía fuertes vínculos con varios dirigentes de las Ligas Agrarias, mientras que su estrecho colaborador en la cooperativa y que residía en la Misión, el exseminarista Orlando Montero, era un cuadro de Montoneros ${ }^{7}$ (Lanusse, 2007).

En ese marco, a partir de 1972 los cooperativistas son hostigados en repetidas oportunidades por fuerzas del ejército y de la policía rural, y sufren allanamientos y requisas. Por su parte, según reconstruye Lanusse (2007), la población que se reconoce como indígena comienza a organizarse en "una federación que nucleara y defendiera los derechos de todos los indígenas de la provincia y a apoyar activamente

7 Montoneros fue una de las organizaciones político-militares más importantes en Argentina hacia finales de los años sesenta. Inscrita dentro del llamado "peronismo de izquierda" o "peronismo revolucionario", la organización defendía un proyecto de liberación nacional y confiaba en Perón como líder capaz de construirlo. 
la lucha de las Ligas Agrarias Chaqueñas, y cualquier otra movida en contra de la explotación de los más débiles" (Lanusse, 2007: 116). En dicha Federación Indígena, impulsada por sectores del "peronismo de izquierda", participaban los trabajadores de la cooperativa y con el proceso electoral que se abre en I973, van a apoyar abiertamente la candidatura de Cámpora para presidente de la nación y la de Deolindo F. Bittel para gobernador de Chaco. No obstante, el triunfo del peronismo en ambas instancias no significó un cambio de la situación en Nueva Pompeya. La tensión fue creciendo y en octubre de 1973 Guillermina Hagen fue detenida y trasladada a Sáenz Peña, junto con otros I 5 trabajadores. Fueron liberados luego de alrededor de 20 días. La cooperativa para entonces ya no contaba con el apoyo del Obispado de Sáenz Peña y al poco tiempo, a inicios de 1975, fue intervenida desde Buenos Aires por el Instituto Nacional de Cooperativas, dependiente del Ministerio de Bienestar Social (Iñigo, 200I). Esta medida significó la decadencia de la cooperativa y sus trabajadores retomaron la migración estacional a la cosecha de algodón en la zona de Castelli. Algunos de ellos directamente abandonaron Misión Nueva Pompeya y se instalaron de manera permanente en la ciudad cabecera del departamento de General Güemes.

En términos de clases, con los elementos presentados hasta aquí podemos decir que nos encontramos con una comunidad en la que se asentaba, por un lado, una pequeña burguesía, muy pauperizada, compuesta por unos pocos que se dedicaban a la ganadería de monte -que en el trabajo de Hermitte et al. aparecen identificados bajo el término de "criollos" - y por el comerciante dueño del almacén. Por otro lado se ubicaban los semiproletarios que combinaban su escasa actividad ganadera con el trabajo como cosecheros en las explotaciones de Castelli y, por último, el sector más numeroso de obreros que también participaban de la cosecha y carecían de otros medios de vida. A partir de 1970 la cooperativa pasa a ser el principal empleador. En principio, esta situación no modificó las relaciones sociales: como vimos, los trabajadores ocupados por ella, por lo menos inicialmente, vendían su fuerza de trabajo a cambio de un salario abonado en especie. De todas formas, esta experiencia fue muy acotada en el tiempo: ya a mediados de los años setenta la cooperativa queda desarticulada y la población obrera de Nueva Pompeya retorna plenamente a su condición de reservorio de fuerza de trabajo para las necesidades del capital algodonero. 


\section{Misión Nueva Pompeya en la actualidad: propiedad comuni- taria, empleo estatal y planes sociales.}

Para llegar a Nueva Pompeya desde la capital de la provincia - Resistencia- hay que recorrer $485 \mathrm{~km}$. Si no se va en auto, esa distancia requiere combinar diferentes transportes. Un micro desde Resistencia hasta Juan José Castelli, que es hasta donde llega el asfalto. Luego, una vez allí, siempre y cuando no llueva, se puede seguir a través de una ruta de tierra para completar los $185 \mathrm{~km}$ restantes. Si el clima no acompaña, los caminos se vuelven intransitables y uno queda varado hasta que escampe. Dada esta infraestructura vial, este pequeño tramo puede implicar alrededor de cinco horas de viaje para llegar a destino. El único transporte colectivo que presta este servicio, lo hace solo tres veces por semana y siempre va abarrotado, llevando gente que va o viene para visitar familiares, hacer trámites o atenderse en el hospital. Completar entonces el recorrido desde Resistencia a Nueva Pompeya puede llevarse entre io y 12 horas, contemplando el tiempo que se pierde al tener que combinar diferentes trasportes y siempre que la lluvia no interrumpa el recorrido.

$\mathrm{Al}$ arribar a la localidad uno se encuentra con un pueblo pobre como cualquier otro de la Argentina: una cuadrícula central de calles pavimentadas, rodeada de calles de tierra, casas precarias, chicos descalzos. Mucho movimiento de motos de baja cilindrada, carros tirados por caballos y bicicletas.

Un pueblo como tantos otros, pero con la particularidad de que se asienta sobre 20000 hectáreas de propiedad comunitaria a nombre de una asociación indígena y en donde cerca de $60 \%$ de su población está considerada como perteneciente a la etnia wichi. En efecto, el I9 de diciembre de 1992, las 20 ooo hectáreas de tierras fiscales que conformaron Nueva Pompeya desde sus orígenes como misión franciscana fueron cedidas por el estado provincial a una "asociación indígena" -la Asociación Comunitaria "Misión Nueva Pompeya"-, en calidad de propiedad comunal. ${ }^{8}$ Al

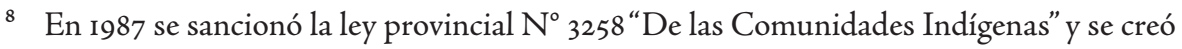
el Instituto del Aborigen Chaqueño (IDACH) como organismo encargado de las políticas públicas que tendría como destinataria específica a la población reconocida como qom (tobas), wichi o moqoit (mocoví). Con estas innovaciones estatales, el derrotero del accionar del movimiento indigenista giró alrededor del cumplimiento de los derechos adquiridos. En particular, de la "recuperación de sus tierras". De esta manera, desde la década de 1990, gran parte de sus fuerzas se centraron en la demanda al Estado de agilizar el otorgamiento de títulos de propiedad comunitaria, tal como fijaba la nueva legislación. A primera vista, su accionar ha rendido frutos. Desde la sanción de la ley, diversas comunidades indígenas formalmente constituidas han conseguido la titulación 
respecto, Marisa Pizzi, única empleada de la oficina de la Secretaría de Agricultura Familiar que funcionó hasta principios de 2016 en esta localidad, y que vive en Nueva Pompeya desde hace más de 20 años, nos informaba:

La asociación que tiene el título es una asociación madre creada ad hoc para recibir el título. Pero en realidad son muchas comunidades, no es una sola. Eso tiene muchas dificultades porque hay unos pocos que tienen el título de todo. Esa asociación se creó para recibir el título. Pero no representa al conjunto de los indígenas, es una figura legal digamos, ese es el problema que tienen. En algún momento propuse que la afiliación, o no sé cómo se diría, a la asociación comunitaria Misión Nueva Pompeya fuera obligatoria para todos, no para algunos. Y no funcionó, entonces algunos son socios y hacen lo que quieren con toda la propiedad que en realidad pertenece a todos. Hay unas IO, I2 asociaciones, la mayoría con personería jurídica, pero el título está a nombre de una sola (entrevista a Marisa Pizzi, exempleada de la Secretaría de Agricultura Familiar, Misión Nueva Pompeya, 13/10/2016).

Por su parte, Paulino, wichí de 38 años, que trabaja de auxiliar docente en una escuela en el paraje Pozo el Sapo nos describió la situación en términos semejantes:

El que tiene el título es la asociación comunitaria que está acá en el centro. Después hay otras asociaciones en los parajes pero que ellos no tienen el título. El que tiene el título es el que está en el pueblo. Nosotros decimos la asociación madre. O sea, cuando el gobierno entregó el título de las 20 mil hectáreas el que recibe es la asociación comunitaria de acá en el centro (entrevista a Paulino, 38 años, auxiliar docente bilingüe, Misión Nueva Pompeya, 29/og/2016).

A su vez, observamos que la población de Nueva Pompeya sigue la misma tendencia en relación con los procesos generales del movimiento de la población provincial ocurridos en las últimas décadas, marcados por la emigración fuera de la provincia, por un lado, y el desplazamiento de la población del ámbito rural a las diferentes ciudades de Chaco, por otro (Muñoz, 2018). En el caso de Nueva Pompeya, dentro de su actual núcleo urbano, la población se ha multiplicado de manera constante.

individual o comunitaria de una superficie total aproximada de 250 ooo hectáreas, fundamentalmente en la región del Impenetrable Chaqueño, a las que hay que sumar las 300 ooo hectáreas de la llamada Reserva Grande, recientemente cedidas en propiedad comunitaria en 2017 (Muñoz, 2018). 
En 2010, la población total era de 4194 habitantes, 2517 de los cuales residían en su planta urbana. Si bien es todavía una proporción reducida en términos relativos, hay que marcar que en I99I solo residían 804 personas donde hoy se asienta el reducido espacio urbanizado. Este crecimiento se basó fundamentalmente en el progresivo asentamiento en el casco urbano de habitantes de los parajes cercanos, ubicados tanto dentro como fuera del "territorio indígena".

De la extensión total de la propiedad, la población se concentra en una porción de no más de 2500 hectáreas, y el resto está cubierto fundamentalmente de monte. El edificio de la antigua misión franciscana, que todavía se conserva, se ubica en el epicentro de la localidad, recientemente urbanizada. En su alrededor se distribuyen casas de material sobre calles asfaltadas, con luz eléctrica y acceso al agua potabilizada. También hay una pequeña sucursal del Banco de Chaco, una planta potabilizadora de agua, un modesto hospital rural con escasos insumos e insuficiente personal, una estación de combustible con dos bocas de expendio, una hostería y algunos mercados. El municipio no cuenta con red de telefonía fija. A mediados de la década de 2000 comenzaron a operar dos compañías de teléfonos celulares. La mayoría de todos estos servicios públicos son de reciente instalación, muchos de ellos brindados a partir de la cautelar de la Corte Suprema de Justicia de la Nación dictada en 2007, que obligó al gobierno provincial a declarar la emergencia sanitaria, alimentaria y educacional de la población clasificada como indígena asentada en esta región. A un costado de la plaza principal se encuentra la casa de los Hermanos Maristas, instalados en la zona desde 1979. Su principal tarea consiste en la administración de la escuela bilingüe Cacique Francisco Supaz, ubicada en el Paraje Pozo del Sapo, a unos $5 \mathrm{~km}$ del pueblo. Se trata de un establecimiento estatal pero de gestión privada a cargo de esta congregación religiosa. Actualmente concurren cerca de I80 alumnos y, según el representante legal del colegio, muchos de ellos van a recibir ahí su única comida en el día. El edificio fue construido en 1994 y hace pocos años fue ampliado para albergar a niños de los tres niveles educativos: inicial, primario y secundario. El proyecto de ampliación estuvo a cargo del estado provincial; brindó empleo de manera precaria a fuerza de trabajo de la comunidad con la idea de enseñarles un oficio a los indígenas, que les permitiera tener mayores posibilidades de inserción laboral. Presentado como una suerte de capacitación, implicaba trabajar cinco horas diarias en tareas de construcción por las que recibían un estímulo en dinero de $\$ \mathbf{1} 900$. Hubo quejas de los obreros, pero se diluyeron al reducirse la cantidad de horas exigidas por día por la misma paga.

A una distancia de entre cinco y diez kilómetros en diferentes direcciones desde allí se ubican los parajes rurales con población dispersa, constituidos alrededor de 
algún pozo de agua; los más grandes son el ya nombrado Pozo El Sapo, hacia el sur, y Pozo del Toba, hacia el oeste. La población de esta periferia rural vive en ranchos hechos de barro, madera y paja, sin luz eléctrica y solo consume agua de lluvia que se acumula en pozos realizados en la tierra (en la parte urbana hay acceso a agua tratada, aunque mantiene altos contenidos de arsénico). Como varios de estos pozos no están cercados, allí también beben, dejan sus excrementos y mueren los pocos animales que tienen algunos pobladores, lo que los convierte en un foco infeccioso perfecto. Un estudio realizado en el paraje Sapo del Pozo en 2007 detectó que 92\% de los niños padecían parasitosis intestinales que pueden ser transmitidas ya sea por el consumo de agua no segura o bien de verduras crudas lavadas con aguas contaminadas (Garbossa, 2009). Esto mismo implica que la higiene personal sea casi imposible y que proliferen todo tipo de enfermedades. La extrema escasez de agua, a su vez, hace que las actividades de autosubsistencia promovidas desde diferentes instituciones estatales, como el cultivo de algunas hortalizas o la apicultura, no logren prosperar. En particular, se han impulsado huertas en el marco del programa PROHUERTA que administra el INTA, que han encontrado un límite inmediato ante la dificultad de acceder a fuentes de agua. Como nos indicaba la empleada a cargo de la Secretaría de Agricultura Familia:

por el ProHuerta yo recibía semillas y le doy a la gente pero es una cosa así medio light, no es que me dedico al tema porque realmente estamos en una zona que si no tenés agua segura... y aun teniendo agua las temperaturas son tan altas que vuelve imposible ese tipo de emprendimientos (entrevista a Marisa Pizzi, ex empleada de la Secretaría de Agricultura Familiar, Nueva Pompeya, 13/10/2016).

Algunos grupos de familias se han dedicado, en el marco del Proyecto de Desarrollo Rural de las Provincias del Noreste Argentino (prodernea) impulsado por la ex Secretaría de Agricultura, Ganadería y Pesca de la Nación, a la producción de miel. Aunque, a diferencia de las huertas, esta actividad no depende del agua, de todos modos su capacidad productiva apenas alcanzaba para el autoconsumo, y su comercialización resultaba insignificante (FIDA, 2009).

Por su parte, si bien existe la producción de artesanías, generalmente realizada por las mujeres, su comercialización también es muy limitada. Uno de nuestros entrevistados señalaba que:

En esta zona se comercializa muy poco la artesanía. Se paga poco, si una artesana quiere vender una linda bolsa o cartuchera a $\$ 70$ la gente no compra. Como ella 
necesita, baja, sigue bajando y si llega a \$20, \$30, sí te compran, pero no saben el trabajo que ello implica, es muy trabajoso (entrevista a Paulino, 38 años, auxiliar docente bilingüe, Nueva Pompeya, 29/o9/2016).

Y agregaba que esa exigua comercialización estaba atravesada por relaciones clientelares. En el centro de Nueva Pompeya hay un pequeño local que pertenece al gobierno municipal, en manos de la Unión Cívica Radical (UCR) desde hace I5 años, en donde se venden artesanías: "Eso lo manejaba una concejala, una criolla, que ella compraba las artesanías y gestionaba los proyectos. Pero nunca llegan. Es la política, si una artesana va, le dice ‘'sos peronista?, bueno te compro pero bajame el precio' (entrevista a Paulino, 38 años, auxiliar docente bilingüe, Nueva Pompeya, 29/09/2016).

El trabajo de campo, realizado en diferentes estadías a lo largo de 20i6, nos permitió observar que se han profundizado algunas tendencias ya presentes de manera más matizada en periodos anteriores, como la reducción del número de gente que practica la marisca (caza y recolección). En 1998 solo $27 \%$ declaró practicarla, y en casi ninguno de estos casos se trata de su actividad principal (Iñigo, 200I). Si bien este porcentaje era bajo, representaba a una cuarta parte de la población activa. En cambio, al momento de nuestro trabajo de campo todos nuestros informantes aseguraban que la "marisca" era una actividad prácticamente inexistente en la actualidad. La mayoría de ellos explican su abandono por la proliferación de planes sociales de asistencia:

no, ya no, muy poco... hay, lo que pasa es que hay mucho, muchas cosas nuevas, como ser las pensiones que no hubo antes, ya hay ahora y la gente se mantiene con eso y ya no busca más pescado, no busca más conejo que hay todavía (entrevista a Felipe, wichi de 7I años, Misión Nueva Pompeya, 15/10/2016).

Acá no tanta marisca, no sé más adelante, más campo adentro... (entrevista a José, wichí de 65 años, Misión Nueva Pompeya, 06/10/2006).

Marisca, muy poco. Planes y changas, la limpieza de terrenos, limpieza de calles, en la municipalidad. (entrevista a Rubén, wichi de 26 años, Misión Nueva Pompeya, o8/10/2016).

En charlas informales durante nuestro trabajo de campo notamos que las personas ancianas solían tener una mirada nostálgica por el abandono de esta actividad. 
Lamentaban que no fuera una práctica valorada entre los más jóvenes, que preferían consumir otro tipo de alimentos. Sin embargo, ellos mismos actualmente tampoco realizaban esta tarea. Sin dejar de desconocer este elemento subjetivo, parece haber una relación directa entre el acceso a ingresos regulares -a través de planes sociales-, que permiten adquirir bienes en el mercado, con la pérdida de peso de la marisca como mecanismo de subsistencia. En ese sentido, podemos entender la marisca como una actividad que se realiza cuando se ven forzados a ello en el momento en que el capital los expulsa del ámbito capitalista de producción y no cuentan con otras vías de ingreso.

Más significativo aún es que en el trabajo de campo ya citado de 1998, más de $70 \%$ de los encuestados habían ido en algún momento de su vida a la cosecha de algodón. Ese año, luego de una breve pero significativa expansión, marca la crisis del sistema algodonero en la provincia. El auge de los años previos se había asentado sobre las explotaciones más grandes y el avance de la mecanización de la cosecha. De todas formas, los altos precios también habilitaron la puesta en producción de explotaciones más ineficientes, que mantuvieron la cosecha manual. Esto explica que todavía a finales de los noventa siguió teniendo una importancia relativa la demanda de fuerza de trabajo para esa tarea. No obstante, en pocos años, con la drástica reducción de la superficie cultivada con algodón ante la crisis y su reemplazo por soya, esta posibilidad de empleo temporal prácticamente desaparece para los obreros de Nueva Pompeya. Ninguna de las personas que entrevistamos en nuestro trabajo de campo en 2016 se había empleado en la cosecha de algodón en los últimos años, ni tampoco pudieron indicarnos algún vecino que sí lo hubiera hecho. Como nos contaba uno de nuestros entrevistados que había comenzado a trabajar como cosechero durante el auge de esta actividad a mediados de la década de 1990: "Yo soy cosechero. Toda mi familia es cosechera. Siempre fui a Castelli, a colonias cerca de Castelli para cosechar. Pero hoy por hoy no hay, no hay gente que coseche el algodón. Hay, pero con máquinas, ya no se ocupa a las personas" (entrevista a Paulino, 38 años, auxiliar docente bilingüe, Nueva Pompeya, 29/o9/2016).

A su vez, la expansión del cultivo de la soya a expensas del algodón que experimenta la provincia más recientemente, por la reducida fuerza de trabajo que requiere, no habilita un proceso de migración estacional de obreros transitorios como ocurría con el algodón. ${ }^{9}$ En ese contexto, cobra cada vez mayor peso entre los obreros ocupados el empleo estatal (tendencia que ya estaba presente y ahora se profundiza).

$9 \quad$ Luego de un breve auge algodonero que vivió Chaco en la segunda mitad de la década de I990, que significó alcanzar la mayor cosecha en la historia de la provincia, la caída 
El censo de población de $200 \mathrm{I}$ ya indicaba la consolidación de esta tendencia en cuanto a las formas de inserción de la pea de Nueva Pompeya a las que hicimos referencia. En el Cuadro i se observa claramente el peso relevante del empleo estatal entre los obreros ocupados de Nueva Pompeya. En parte, esto fue estimulado a partir de la legislación indigenista que se implementó en la provincia hacia finales de la década de 1980, que implicó la creación de cargos públicos que debían ser cubiertos por personas que se identificaran como indígenas, tales como auxiliares docentes y agentes sanitarios bilingües. Previamente, en 1984, se adoptó una resolución que indicaba que $6 \%$ de las vacantes de la policía provincial debían ser cubiertas con indígenas. En cuanto al sistema de salud, se incluyó la figura del promotor de salud o agente sanitario. En la región de El Impenetrable chaqueño, a mediados de la década de 2000 había 90 agentes sanitarios elegidos entre las diferentes asociaciones indígenas asentadas en la zona. Para ello recibieron una capacitación mínima en los centros de Castelli y Sáenz Peña. Sus funciones habituales consistían en la detección de casos y la distribución de los recursos del Plan Materno-Infantil de la provincia.

\section{Cuadro i.}

Población ocupada según categorías ocupacionales, Municipio de Nueva Pompeya, 2001.

\begin{tabular}{llll}
\hline Categoría de trabajador & Nueva Pompeya & Chaco & País \\
\hline Obrero o empleado en el sector público & 43.25 & 26.65 & 21.20 \\
\hline Obrero o empleado en el sector privado & 17.85 & 28.26 & 48.94 \\
\hline Patrón & 2.89 & 5.68 & 6.24 \\
\hline
\end{tabular}

de los precios internacionales, combinada con las inundaciones de 1997 y 1998, destruyó la producción y facilitó su reemplazo por la soya transgénica. Mientras que la superficie implantada con algodón pasó de 712 000 hectáreas en 1997/98 a solo 89000 en 2002/2003, la oleaginosa creció de II5 000 a 768000 hectáreas en el mismo periodo. El avance soyero en detrimento del algodón implicó una fuerte caída en la demanda de fuerza de trabajo requerida en el agro chaqueño, ya que todas las tareas implicadas en la producción de la oleaginosa no suman más de cuatro horas/hombre de trabajo por hectárea al año (Preda y Blanco, 20I0). En este contexto, se profundiza una tendencia de larga data en el agro chaqueño: no se puede retener a la población creada al calor del auge algodonero, que desde la década de 1960 comienza a ser expulsada hacia áreas urbanas tanto dentro como fuera de la provincia. En efecto, una de las primeras manifestaciones del estancamiento general de la provincia y la crisis de su principal sector productivo hacia finales de esa década fue la tendencia negativa de su tasa de crecimiento demográfico. Tendencia que no se relaciona con un crecimiento vegetativo negativo de la población, sino con la continua emigración de chaqueños (Ferreras, 2010) 


\begin{tabular}{llll}
\hline Trabajador por cuenta propia & 29.10 & 23.27 & 20.26 \\
\hline Trabajador familiar & $6.9 \mathrm{I}$ & 6.15 & 3.37 \\
\hline
\end{tabular}

Fuente: Ministerio del Interior. Datos de Municipios, 20Io,

De acuerdo con la distribución indicada en el Cuadro I, podemos sostener que, en principio, la transformación de la tierra fiscal en propiedad comunitaria no produjo, en relación con las formas de reproducción social de esta población, un cambio en las relaciones sociales de producción. Es decir, con el acceso a la tierra no hubo un aumento de la población ocupada en tareas de autoconsumo (que aparecen reflejadas en el cuadro como trabajadores por cuenta propia y trabajadores familiares).

En cambio, sí tiene un impacto la significativa reducción de la cosecha manual del algodón, actividad que no ha sido reemplazada por otras alternativas que requieran una fuerza de trabajo de magnitudes semejantes. Esta transformación se refleja en la caída del porcentaje de obreros empleados en el sector privado.

En ese contexto, desde finales de la década de 1990 comienzan a implementarse a nivel local, de manera todavía muy acotada, los planes y programas nacionales de asistencia a la pobreza y la desocupación (Planes Trabajar). Así, a mediados de la década de 2000 se van a hacer más extensivos y desde entonces el grueso de la población subsiste principal y casi exclusivamente de planes sociales de asistencia y pensiones por invalidez (la mayoría que recibe este ingreso lo hace por estar afectados por el Mal de Chagas): "Ese es el único ingreso de cada familia, si no es empleado público, no es municipal, espera eso nomás, asignación universal, pensión, sí, hay muchos planes aquí" (entrevista a Paulino, 38 años, auxiliar docente bilingüe, Nueva Pompeya, 29/og/2016).

Hay gente que trabaja en la parte de educación, como auxiliares docentes, después otros trabajan en la municipalidad, otros trabajan en los comercios como changarines, eso es lo que hay digamos, no hay mucho trabajo. Hay muchas pensiones por chagas, casi todos tienen chagas. Yo creo que los planes sociales cambiaron un poco la situación. En los últimos años la desnutrición disminuyó mucho. Cuando yo llegue acá, hace 20 años, llevaba los cajoncitos para enterrar a los chicos en mi auto, morían como moscas los chicos, terrible (...) Yo he visto a la gente morir de hambre literalmente. Vos ibas a la mañana a una casa y la gente estaba en la cama, estaban ahorrando calorías, no tenían nada para comer y se quedaban en la cama. (entrevista a Marisa Pizzi, exempleada de la Secretaría de Agricultura Familiar, Nueva Pompeya, 13/10/2016). 
La desgarradora descripción contenida en este último testimonio coincide con la información recabada en un trabajo realizado en 2013 por investigadores de Flacso a pedido de Unicef (Isla y Vezza, 2013), que indicaba que:

testimonios recogidos en Nueva Pompeya señalan que hace cuatro años eran frecuentes las muertes de bebés y niños por desnutrición, diarrea y causas relacionadas. Y que las familias indígenas lo tomaban con desesperación por su alta probabilidad. De hecho, en todas las familias wichí se constata la pérdida de hijos (Isla y Vezza, 2013: 33).

Si bien hay diferentes programas de intervención destinados a esta población, muchos de ellos resultan incompatibles entre sí o bien requieren trámites difíciles de cumplir, lo que impide ser beneficiario de diferentes programas de asistencia al mismo tiempo. Por ejemplo, el informe elaborado por Isla y Vezza (2013) se detectó que algunas familias de Nueva Pompeya prefieren hacer el trámite para una pensión o para una jubilación y no el que les permite acceder a la Asignación Universal por Hijo (AUH). Ello se debe, en parte, a que en muchos casos los niños están bajo el cuidado de abuelos o tíos, lo cual implica realizar previamente trámites de tenencia legar para obtenerla, algo muy dificultoso en particular para los habitantes de Nueva Pompeya que, ubicada en el corazón del Impenetrable, hasta 2016 no contaba con un juzgado para poder realizarlo. Por otra parte, los que reciben la pensión por invalidez (que en 201 constaba de un ingreso de \$1 ०००), quedan impedidos de acceder a la AUH. Respecto a este último programa, de carácter más universal, el mismo informe señala que en el relevamiento que realizaron en 201 en Nueva Pompeya, ninguno de los entrevistados cobraba los $\$ 180$ mensuales $y$, a fin de año, los $\$ 40$ mensuales restantes si se habían cumplido las condicionalidades impuestas por el programa. Por el contrario, la mayoría declaró cobrar solo \$150. Al respecto, un informante clave nos comentaba que muchos no tienen un conocimiento claro de los ingresos que estipulan estos programas, lo que facilita que sean estafados por gestores, comerciantes y empleados bancarios.

Ahora el problema que hay es que la gente se engancha en cuotas, en compra de cosas, y ahora no les está alcanzando, así que me paso los días a la mañana haciendo notas para el banco para que no les debiten más. Además, vienen por ejemplo los vendedores y presionan a la gente para que firmen y la gente no tiene la cultura de negarse, de decir no, esto no. El tipo viene le habla fuerte, la presiona y la gente firma sin saber que después lo que va a hacer es sacarle de la cuenta del banco. [...] Nosotros 
hemos detectado pagos que no se hacían, o sea que [el banco] les daba menos de lo que correspondía. Incluso hemos denunciado, más de una vez he denunciado en el banco a cajeros. Por ejemplo viene uno, y la gente no está enterada de cuándo es el aumento, cuánto es. Me acuerdo una vuelta que venían pagando la pensión \$1800 y de repente subió a $\$ 2400$ y le seguían entregando $\$ 1800$ a la gente (entrevista a Marisa Pizzi, exempleada de la Secretaría de Agricultura Familiar, Nueva Pompeya, I4/10/2016).

En el mismo sentido, Rolando Núñez, director del Centro de Estudios Sociales Nelson Mandela, con una larga trayectoria de trabajo en la zona, nos explicaba que al momento de lanzarse los primeros planes de asistencia, Nueva Pompeya todavía no contaba con una dependencia del Banco Chaco. Había que ir a retirar el dinero a Castelli, algo prácticamente inviable para estas familias. El intendente de entonces se encargaba de retirar todo el dinero y los beneficiarios tenían que pasar a cobrar por su oficina en el municipio (comunicación personal de Rolando Núñez, director del Centro de Estudios Sociales Nelson Mandela, 09/2016). El gesto del intendente fue especialmente útil para controlar disidentes y conformar una extensa clientela política propia: 15 años después sigue reteniendo la intendencia, de manera ininterrumpida. En fecha reciente, como dijimos, se instaló una sede del Banco de Chaco que permitió que los beneficiarios de planes sociales puedan retirar personalmente su subsidio. Una de nuestras estadías en Nueva Pompeya coincidió con la fecha de pago. Ese día, el pueblo adquiere especial efervescencia. A los habitantes del ejido urbano se suman los que viven en los parajes rurales circundantes. Todos hacen el mismo circuito, metódicamente. Del cajero a cargar combustible en sus motos y de ahí al mercado a comprar harina y aceite. La dieta es fundamentalmente hidratocarbonada, tanto es así, que la forma común de comprar harina es en bolsas de 50 kilos. Con esa alimentación, informes realizados en la zona indican que $23 \%$ de los bebés de hasta un año de edad están desnutridos, mientras que a partir de los 12 meses, cuando en general dejan de ser amamantados, el porcentaje aumenta a cifras cercanas a 60\% (Giombini et al,, 2005).

Otro elemento que interviene en la reproducción de esta población es la caridad privada. Tan solo lo consignamos, sin poder indicar efectivamente su relevancia, dada la dificultad de medir este tipo de ayuda. Tanto a título personal como en representación de algún grupo o institución, diversas personas de distintos lugares del país o grupos de los más variados, realizan colectas de alimentos, ropa y otros elementos para distribuir tanto en Nueva Pompeya como en otros parajes y locali- 
dades del Impenetrable Chaqueño. Al respecto, uno de nuestros entrevistados, que vive en uno de los parajes rurales de Nueva Pompeya, nos decía:

Hay mucha gente que viene de lejos y siempre colabora, traen ropa. Antes era muy difícil la ropa y ellos vienen y traen ropa, mercadería, cuadernos, alguna cosita que nosotros necesitamos. Hay épocas que no llueve acá, mucha sequía. Y vienen, nos visitan no sé si de Rosario, Córdoba y traen agua mineral y nos dan a nosotros (entrevista a José, wichí de 65 años, Nueva Pompeya, 06/10/2006).

Por último, por fuera de esta caracterización general, una vía de ingresos novedosa se abrió para un sector muy minoritario de la población a partir de la entrega de estas tierras en propiedad comunitaria. Durante nuestro trabajo de campo, recurrentemente, pasado el mediodía, la vida en el pueblo se apaga casi por completo y se activa el movimiento en los caminos: camiones repletos de troncos de algarrobo que salen de diferentes puntos del monte. Desde 1999 rigen en la provincia las disposiciones del Decreto $\mathrm{N}^{\circ}{ }_{1702 / 99}$, que en su artículo I establece: "Facúltase al Ministerio de la Producción para que a través de la Dirección de Bosques, dependiente de la Subsecretaría de Recursos Naturales y Medio Ambiente, autorice permiso de aprovechamiento forestal a las Asociaciones Aborígenes". Con permisos más o menos legales, los que dirigen la asociación indígena que obtuvo el título de propiedad hacen posible que empresarios forestales talen dentro de estos terrenos. Así,

cuando los madereros piden permisos forestales (...) en un predio criollo, el responsable es el maderero, pero, cuando se dan los permisos en un predio aborigen, el responsable de que se cumpla con la normativa es el indígena. Lo anterior es importante, porque los madereros se aprovechan de la poca capacidad de organización indígena. La ley de Bosques se hizo a favor del aborigen, ellos tienen capacidad de talar cierta cantidad de árboles; sin embargo, como no tienen las herramientas, hacen un arreglo interno con un maderero (Ana Estrada, excoordinadora del Proyecto de Desarrollo Integrado Interfluvio Teuco - Bermejito pDIT B, citado en Ramos, 2010: 197).

Con base en los testimonios que hemos podido recabar, para cerrar estos acuerdos, los capitalistas no requieren más que la cooptación de los referentes oficialmente reconocidos de las comunidades, generalmente a través de dádivas: alguna camioneta, viajes, entre otras cosas, para la comisión directiva de la asociación:"Acá con el corte de madera hay Io, I2 familias que reciben esa plata y que le compran camioneta, auto, pero no son nuevos, son usados, viejitos..." (entrevista a Paulino, 38 años, 
auxiliar docente bilingüe, Nueva Pompeya, 29/o9/2016). Además, hay que agregar que al tratarse de una actividad altamente tecnificada, no redunda en un factor de demanda de fuerza de trabajo dentro de esta población.

\section{Conclusiones}

A lo largo de este trabajo hemos intentado reconstruir las formas de reproducción social de la población de Nueva Pompeya, desde la década de 1970 a la actualidad. Dado que esta localidad presenta la peculiaridad de que cerca de $60 \%$ de su población es calificada como perteneciente a la etnia wichí, hemos puesto especial atención a su posición social en términos de clase.

En ese sentido, pretendimos describir una realidad que está muy lejos de las suposiciones antropológicas dominantes, que intentan transformar ciertas actividades -fundamentalmente la "marisca" (extracción de productos del monte circundante)en supuestas prácticas contra-hegemónicas que les permitirían una independencia relativa respecto de la explotación capitalista y las relaciones asalariadas. Muy por el contrario, esta población presenta condiciones de vida y de trabajo similares a las de otras fracciones de la misma clase obrera. $\mathrm{Al}$ respecto, a partir de estudios de caso, otros autores también han mostrado cómo la marisca es practicada tanto por los pobladores que se reconocen como indígenas como quienes no se adscriben a tal identidad (Balazote, 2002). Como vimos, hay una reducción de la demanda de fuerza de trabajo en las tareas requeridas por el cultivo de algodón, un crecimiento del empleo público y, más recientemente, la implementación de planes de trabajo y programas de asistencia a la pobreza como paliativo a la desocupación. En forma concomitante se verifica un proceso acelerado de expulsión de esta población del ámbito rural hacia la planta urbana de Nueva Pompeya, que generó la aparición de "changas" propias de los ámbitos urbanos.

De esta manera, consumado el proceso de proletarización hace más de Ioo años cuando comienzan a incorporarse como cosecheros de algodón, sostenemos como hipótesis a desarrollar en otros trabajos que la tendencia general que se manifiesta en las últimas décadas es el pasaje de esta fracción de la clase obrera argentina de su condición de sobrepoblación relativa latente a estancada, en el caso de los que logran migrar a las ciudades, o el hundimiento en el pauperismo consolidado, los que todavía continúan en los espacios rurales (Marx, 2004). Expulsados del proceso productivo, debido a los cambios técnicos ocurridos en la producción algodonera y el avance de la soya, solo muy parcialmente son reincorporados en actividades urbanas. El 
título que hemos dado al trabajo hace referencia a las implicancias sociales de esa transformación económica. ${ }^{10} \mathrm{Al}$ respecto, son elocuentes los niveles actuales de desnutrición y mortalidad infantil que padece esta población, particularmente las llamadas comunidades aborígenes. Esta situación, a su vez, no es privativa de esta localidad. En 2007, luego de una sucesión de muertes por hambre, el gobierno provincial se vio obligado a firmar un decreto que declaraba en estado de emergencia sanitaria, alimentaria, educacional y habitacional a "los pueblos indígenas" de la provincia del Chaco. ${ }^{11}$ No obstante, su aplicación no ha modificado de manera sustantiva las condiciones de miseria en las que viven. En Misión Nueva Pompeya, a su vez, la transformación de estas tierras en "propiedad comunitaria indígena" a partir de la década de 1990 no ha significado hasta el momento un cambio en la forma de reproducción social de esta población y, por tanto, tampoco en su inserción social en tanto obreros, mayormente desocupados, dentro de la estructura de clases.

${ }^{10}$ El título hace referencia a su vez a un trabajo clásico de la antropología chaqueña: De la algarroba al algodón. Movimiento mesiánico de los guacurú, de Cordeu y Siffredi, publicado en 1971. Los autores aludían con ese título al cambio de las relaciones sociales en que los grupos indígenas cazadores-recolectores -en cuya reproducción jugaba un papel importante la algarroba- pasaron a convertirse en obreros rurales, fundamentalmente en la cosecha del algodón. Nuestro trabajo aborda un periodo posterior, en el que esa población incorporada al sistema algodonero, ante su crisis y reconversión, es expulsada sin mayores oportunidades de encontrar ocupación en otras actividades.

${ }^{11}$ El decreto expresa entre sus puntos "que el fallecimiento de miembros de los Pueblos Indígenas Qom, Wichí y Mocoví, que vienen sucediendo desde un largo periodo de tiempo por causas evitables (...) que el Estado chaqueño debe dar solución de manera pronta y eficaz conformando un Comité de Crisis, autorizándose a requerir la asistencia de la Organización Mundial de la Salud, Unicef, Cruz Roja Argentina, entidades profesionales de la salud, Universidades Nacionales, CGT, CTA, entidades intermedias, sindicatos afines $u$ otras entidades nacionales e internacionales a los fines de brindar ayuda a la población indígena para evitar que se sigan perdiendo y deteriorando las vidas de ancianos, madres, niños, hombres". Decreto provincial no ${ }^{\circ} 15$ aprobado el 17/12/2007. 


\section{Bibliografía}

Balazote, Alejandro

2002, "Reasentamiento forzoso de población y regularización territorial en el Interfluvio Teuco-Bermejito (Provincia de Chaco)", Cuadernos de Antropología Social, I6, agosto-diciembre, Buenos Aires.

Besil, Antonio

1970, Evolución bistórica de la Actividad Algodonera en la República Argentina y en la Provincia del Chaco, Resistencia, s./d.

Bórmida, Marcelo

1969, "Mito y Cultura", Runa: Archivo para las Ciencias del Hombre 12, pp. 9-52. Bórmida, Marcelo

1976, Etnología y Fenomenología, Buenos Aires, Cervantes.

Colombres, Adolfo

2004 La colonización cultural de la América Indígena, Buenos Aires, Editorial del Sol.

Cordeu, Edgardo y Alejandra Siffredi

I97I, De la algarroba al algodón: movimientos milenaristas del Chaco argentino, Buenos Aires, Juárez Editor.

Dalla-Corte Caballero, Gabriela

2014, San Francisco de Asís del Laishí. Sensibilidades tobas y franciscanas en una misión indígena (Formosa, 1900-1955), Prohistoria Ediciones.

Ferreres, Orlando

20II, Chaco, su historia en cifras, Resistencia, Librería de la Paz

Garbossa, Graciela

2009 "La urgencia de agua potable para detener la mortalidad", en Encrucijadas, 48, Universidad de Buenos Aires.

Giombini, Mariano et al.

2005, "Relevamiento del estado nutricional de niños de la comunidad wichí de Nueva Pompeya, provincia de Chaco", Revista Argentina de Antropología Biológica 7(I), p. I54.

Gordillo, Gastón

2006, En el Gran Chaco. Antropologías e historias, Buenos Aires, Prometeo.

Hermitte, Esther y equipo

1995, Estudio sobre la situación de los aborígenes de la provincia del Chaco y politicas para su integración a la sociedad nacional, vols. I, II y III, Editorial Universitaria, Universidad Nacional de Misiones. 


\section{Iñigo Carrera, Nicolás}

1984, Campañas militares y clase obrera. Chaco, 1870-1930, Buenos Aires, CEAL. Iñigo Carrera, Nicolás

I999, “ ¿Reserva o excluidos? El caso de la población aborigen y criolla en una localidad del Impenetrable chaqueño (I970-1998)", Anuario IEHS.

Iñigo Carrera, Nicolás

200I, "Nuevamente sobre la violencia como potencia económica: análisis del papel del estado en el desarrollo de una comunidad chaqueña, 1969-80", en Ana Teruel et al., Fronteras, ciudades y estados, Córdoba, AlciónunLu. vol. I.

Isla, Alejandro y Evelyn Vezza

2013, "El acceso a la Asignación Universal por Hijo en los Pueblos Indígenas del Norte argentino", Fondo de las Naciones Unidas para la Infancia (Unicef), Flacso.

Lanusse, Lucas

2007, Cristo revolucionario. La Iglesia militante, Buenos Aires, Javier Vergara Editor.

Manoiloff, Raúl

200I, El cultivo del algodón en el Chaco entre 1950 y nuestros días, Resistencia, Chaco, Ed. Meana y Meana.

Miranda, Guido

1955, Tres ciclos chaqueños. Crónica bistórica regional, Resistencia, Chaco.

Moglia, Leandro

2007,"Los efectos de la crisis económica de 1930 en el sector cooperativo agrícola del Territorio Nacional del Chaco". Ponencia presentada en el 1er. Congreso Latinoamericano de Historia Económica, diciembre, Montevideo, Uruguay.

Moglia, Leandro

2008, "El movimiento cooperativo agrícola del Chaco entre los Gobiernos de Regulación y Planificación (I930-I955)". Ponencia presentada en las XXI Jornadas de Historia Económica, publicada en http://xxijhe.fahce. unlp.edu.ar/

Moglia, Leandro

20II, "Conflicto en el Territorio Nacional del Chaco. Las Cooperativas agrícolas frente al Estatuto del Peón Rural", Mundo Agrario, II(22), enero-junio, La Plata. 
Marx, Karl 2004, El Capital, tomo I, vol. 3, Cap. 23, Siglo xxi Editores.

Muñoz, Roberto

2016, "Organizaciones campesinas en la provincia de Chaco, Argentina. Una aproximación a su composición social a partir de sus acciones de protesta: el caso de la Unión Campesina de Chaco (UCC), 2002-2011", en -1@tina. Revista electrónica de estudios latinoamericanos, I4(55), pp. 23-43.

Muñoz, Roberto

2018 Formas de reproducción social y organización politica de la "población indígena" en la provincia de Chaco, 1983-2017, tesis de doctorado inédita, Facultad de Filosofía y Letras, Universidad de Buenos Aires.

Roze, Jorge Próspero

2004, "Del apogeo y crisis de una burguesía hegemónica al defensismo de una burguesía en disolución. El caso del Chaco 1970-2000”, Revista Theomai,

Sartelli, Eduardo 9, primer semestre.

1996,"Celeste, blanco y rojo. Democracia, nacionalismo y clase obrera en la crisis hegemónica", Razón y Revolución, 2, Buenos Aires, Argentina.

Schaller, E.

I999, "La política de Tierras y la Colonización en la Provincia del Chaco (I870I990)". Ponencia presentada en el X Congreso Nacional y Regional de Historia Argentina, Santa Rosa, Academia Nacional de la Historia.

Teruel, Ana

2005, Misiones, economía y sociedad. La frontera chaqueña del Noroeste argentino en el siglo XIX, Universidad Nacional de Quilmes, Buenos Aires.

Trinchero, Hugo (comp.)

1995, Producción doméstica y capital, Buenos Aires, Ed Biblos.

Trinchero, Hugo

1998 Antropología Económica, Buenos Aires, Ed. Eudeba.

\section{Otras fuentes}

Argentina. Poder Ejecutivo: Decreto del 20 de marzo de I9I4.

Cámara de Diputados de la Provincia de Chaco. Ley N³258/87 "De las Comunidades Indígenas". 
Instituto Nacional de Estadística y Censos (INDEC) Censo Nacional de Población y Vivienda 200I.

Instituto Nacional de Estadística y Censos (INDEC). Encuesta Complementaria de Pueblos Indígenas (ECPI) $2004-2005$.

Instituto Nacional de Estadística y Censos (INDEC). Censo Nacional de población, hogares y vivienda 20IO. Censo del Bicentenario, pueblos originarios: región NEA, 2015.

Fondo Internacional de Desarrollo Agrícola (FIDA) (2009) Proyecto de Desarrollo Rural de las Provincias del Nordeste (prodernea). Evaluación final.

Secretaría de Trabajo y Previsión. Consejo Agrario Nacional: "El problema indígena en Argentina". Buenos Aires, 1945.

Reglamento para el régimen de las Misiones Franciscanas del Chaco Argentino, 1928.

Roberto Muñoz

Licenciado en Sociología y doctorado en Historia por la Universidad de Buenos Aires. Becario posdoctoral del Consejo Nacional de Investigaciones Científicas y Técnicas (CONICET) con sede de trabajo en el Instituto de Investigación en Humanidades y Ciencias Sociales (IdihCs-unlpConicet) e investigador en el Centro de Estudios e Investigación en Ciencias Sociales (CEICS). Su tesis de doctorado, defendida en 20I8, se centró en las formas de reproducción social y organización política de la población reconocida como indígena en la provincia de Chaco, Argentina. Actualmente trabaja sobre las organizaciones cooperativas de la pequeña burguesía y la clase obrera rural en la misma provincia, desde la descomposición de las Ligas Agrarias. También ha publicado artículos de divulgación científica acerca de las condiciones de trabajo en diferentes producciones agrarias extrapampeanas, particularmente el caso de los cosecheros de yerba mate en Misiones y los trabajadores del arándano en Entre Ríos. Asimismo, ha participado en congresos y jornadas científicas nacionales e internacionales, en los que se han discutido sus trabajos sobre estas temáticas. 
Citar como: Roberto Muñoz (2020), "Del algodón al desempleo: la "población indígena" en Misión Nueva Pompeya, Chaco: 1970-2016", Iztapalapa. Revista de Ciencias Sociales y Humanidades, núm. 88, año 4I, enero-junio de 20Io, ISSN: 2007-9176; pp. 197-228. Disponible en <http://revistaiztapalapa.izt. uam.mx/index.php/izt/issue/archive $>$. 